\title{
Computer technology: Index to articles in Behavior Research Methods, Instruments, \& Computers from 1988 through 1989
}

\author{
GWENDOLYN CAMPBELL and JOSEPH B. SIDOWSKI \\ University of South Florida, Tampa, Florida
}

This is a supplement to "Computer technology: Index to articles in Behavior Research Methods, Instruments, \& Computers from 1977 to 1987," published in the December 1987 issue. Articles are listed under the various categories in the form of complete reference citations, except for the journal name. If an article is relevant to more than one topic, a complete citation is provided for each.

The Topic Guide lists the categories and subcategories as they appear serially in the Computer Technology Index. If two or more categories contain related material, the Topic Guide refers the reader to the related topics. There have been several minor modifications and additions to the Topic Guide since the original index was published.

Note-All correspondence and requests for reprints should be sent to Gwendolyn Campbell, Department of Psychology, University of South Florida, Tampa, FL 33620. 


\section{Topic Guide}

Artificial Intelligence and Applications $\ldots \ldots \ldots \ldots \ldots \ldots \ldots \ldots \ldots, 658$

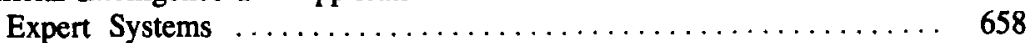

Neural Nets ............................. 658

(See also Simulations and Models, Connectionist Models)

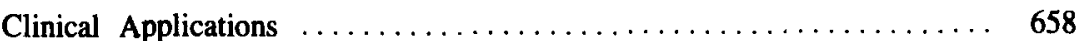

Assessment $\ldots \ldots \ldots \ldots \ldots \ldots \ldots \ldots \ldots \ldots \ldots \ldots \ldots, 658$

(See also Testing, Psychological Testing)

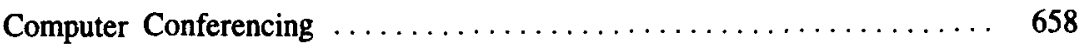

Computer Randomization Techniques $\ldots \ldots \ldots \ldots \ldots \ldots \ldots \ldots \ldots, 658$

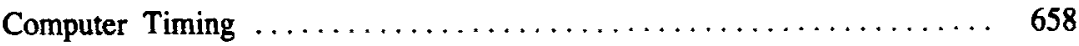

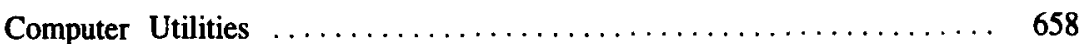

Data Transfer $\ldots \ldots \ldots \ldots \ldots \ldots \ldots \ldots \ldots \ldots \ldots \ldots \ldots \ldots, 65 \% \ldots$

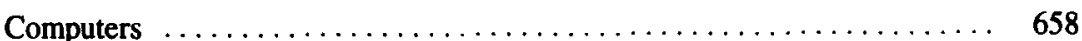

General Use in Psychology $\ldots \ldots \ldots \ldots \ldots \ldots \ldots \ldots \ldots \ldots, 658$

Psychological Theory $\ldots \ldots \ldots \ldots \ldots \ldots \ldots \ldots \ldots \ldots \ldots \ldots, 658$

Selection and Maintenance $\ldots \ldots \ldots \ldots \ldots \ldots \ldots \ldots \ldots . \ldots . \ldots 69$

Computers in Education ............................ 659

Computer Aided Instruction (CAI) $\ldots \ldots \ldots \ldots \ldots \ldots \ldots \ldots, 659$

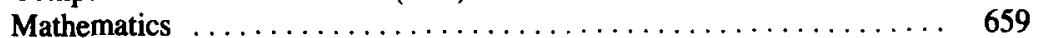

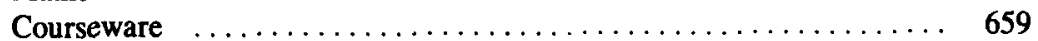

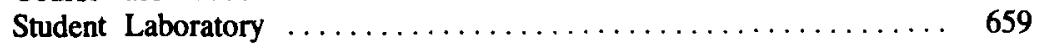

(See also Research Applications; Simulations and Models)

EEG/EMG/ECG ................................. 659

(See also Research Applications, Biopsychology/Psychophysiology)

Experiment Design ................................. 659

(See also Stimulus Generation and Selection; Statistical Analysis)

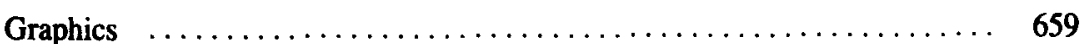

Animation of Graphics $\ldots \ldots \ldots \ldots \ldots \ldots \ldots \ldots \ldots \ldots \ldots, \quad 660$

Software $\ldots \ldots \ldots \ldots \ldots \ldots \ldots \ldots \ldots \ldots \ldots \ldots \ldots, \quad \mathbf{6 6 0}$

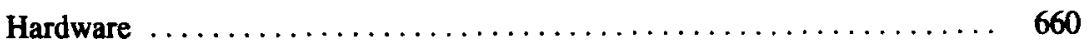

Evaluation and Comparison $\ldots \ldots \ldots \ldots \ldots \ldots \ldots \ldots \ldots \ldots, 660$

CRT Modifications $\ldots \ldots \ldots \ldots \ldots \ldots \ldots \ldots \ldots \ldots \ldots, \quad 660$

(See also Visual Display System)

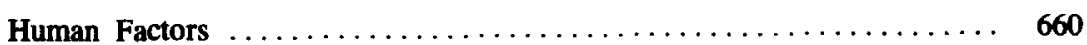

Human-Computer Interaction $\ldots \ldots \ldots \ldots \ldots \ldots \ldots \ldots \ldots \ldots, \quad 660$

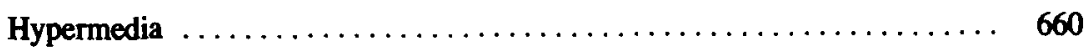

HyperCard $\ldots \ldots \ldots \ldots \ldots \ldots \ldots \ldots \ldots \ldots \ldots \ldots, \quad 660$

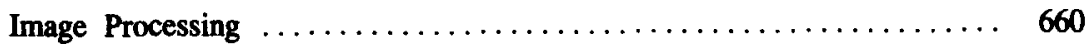

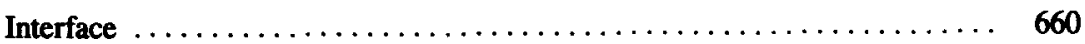

(See also Laboratory Control Program; Research Applications)

Laboratory Control Program ......................... $\quad 660$

(See also Interface; Research Applications)

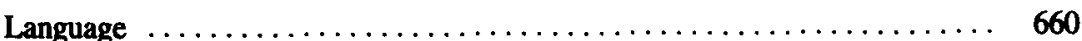

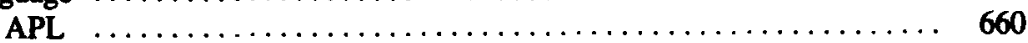

Assembler/Machine Language $\ldots \ldots \ldots \ldots \ldots \ldots \ldots \ldots \ldots \ldots, \quad 661$

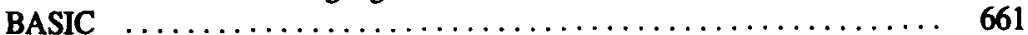

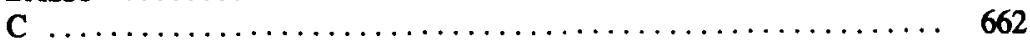

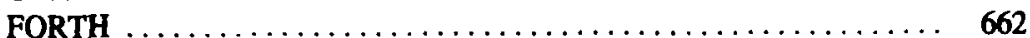

FORTRAN $\ldots \ldots \ldots \ldots \ldots \ldots \ldots \ldots \ldots \ldots \ldots \ldots \ldots \ldots, \quad 662$

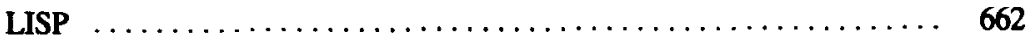

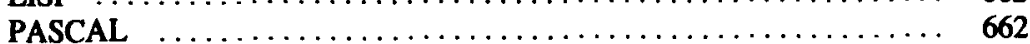

Motor Behavior $\ldots \ldots \ldots \ldots \ldots \ldots \ldots \ldots \ldots \ldots \ldots \ldots \ldots \ldots \ldots \ldots, \quad 663$ 
Networking and Timesharing $\ldots \ldots \ldots \ldots \ldots \ldots \ldots \ldots \ldots \ldots \ldots$

Observational Methods $\ldots \ldots \ldots \ldots \ldots \ldots \ldots \ldots \ldots \ldots \ldots \ldots \ldots \ldots \ldots$

Recorders $\ldots \ldots \ldots \ldots \ldots \ldots \ldots \ldots \ldots \ldots \ldots \ldots \ldots \ldots \ldots \ldots \ldots \ldots$

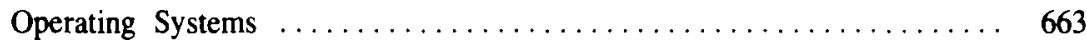

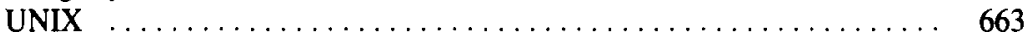

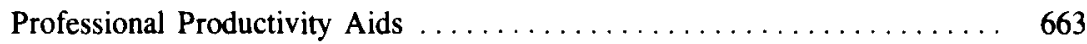

Reference/Reprint Management $\ldots \ldots \ldots \ldots \ldots \ldots \ldots \ldots \ldots \ldots 663$

Programming $\ldots \ldots \ldots \ldots \ldots \ldots \ldots \ldots \ldots \ldots \ldots \ldots \ldots \ldots \ldots \ldots \ldots \ldots$

Computer Languages for Psychology ................. 663

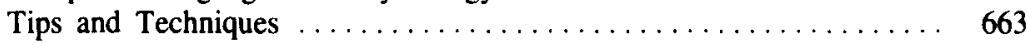

Research Applications $\ldots \ldots \ldots \ldots \ldots \ldots \ldots \ldots \ldots \ldots \ldots \ldots \ldots$

(See also Simulations and Models)

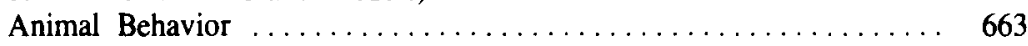

Biopsychology/Psychophysiology $\ldots \ldots \ldots \ldots \ldots \ldots \ldots \ldots \ldots \ldots$

(See also EEG/EMG/ECG)

Cognition and Memory $\ldots \ldots \ldots \ldots \ldots \ldots \ldots \ldots \ldots \ldots \ldots \ldots \ldots \ldots$

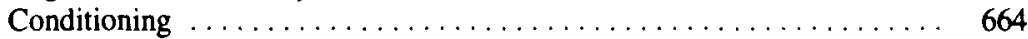

Eye Movement Measurements $\ldots \ldots \ldots \ldots \ldots \ldots \ldots \ldots \ldots \ldots \ldots 64 \ldots \ldots \ldots \ldots$

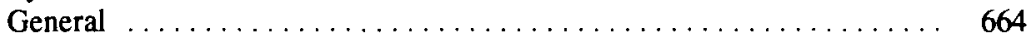

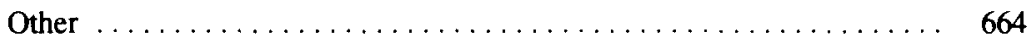

Perception and Sensation $\ldots \ldots \ldots \ldots \ldots \ldots \ldots \ldots \ldots \ldots \ldots 64$

(See also Theory of Signal Detectability)

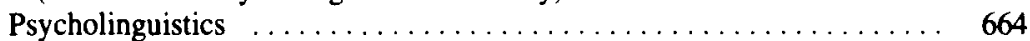

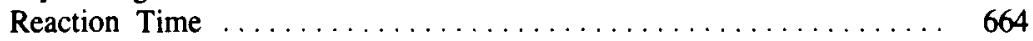

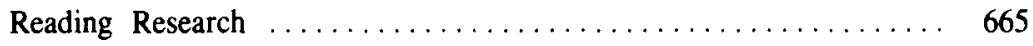

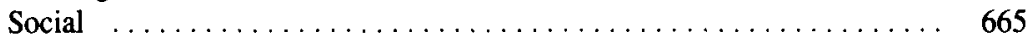

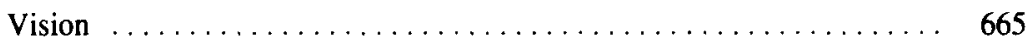

(See also Visual Display System)

Simulations and Models $\ldots \ldots \ldots \ldots \ldots \ldots \ldots \ldots \ldots \ldots \ldots \ldots \ldots$

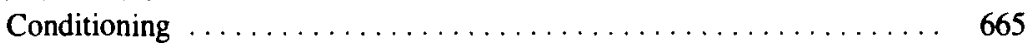

Connectionist Models ........................ 665

(See also Artificial Intelligence and Applications, Neural Nets)

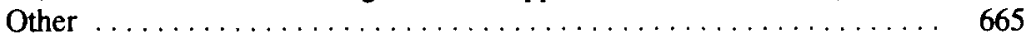

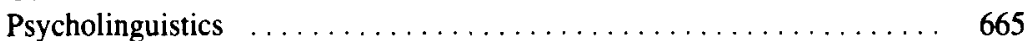

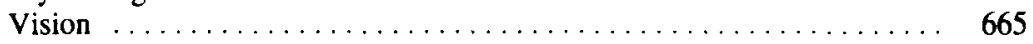

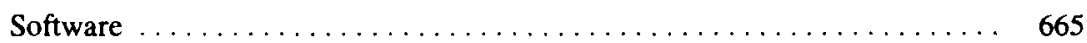

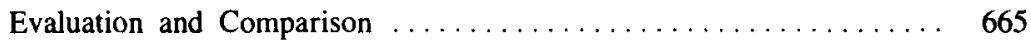

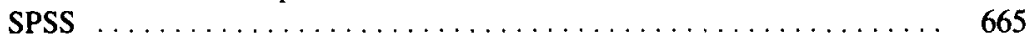

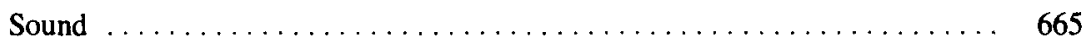

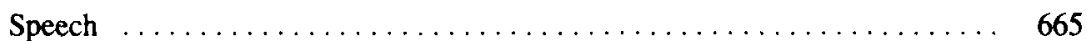

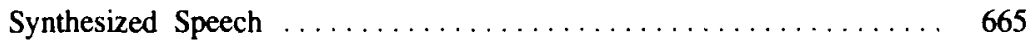

Voice Recognition ........................ 665

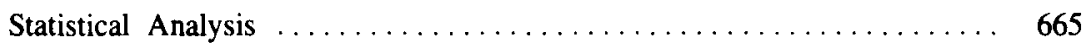

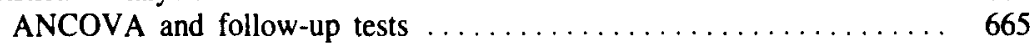

ANOVA and follow-up tests $\ldots \ldots \ldots \ldots \ldots \ldots \ldots \ldots \ldots \ldots \ldots 6,6 \ldots \ldots$

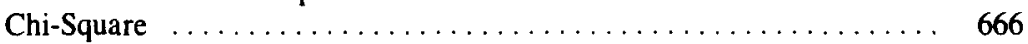

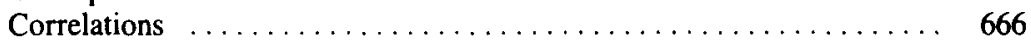

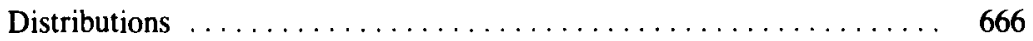

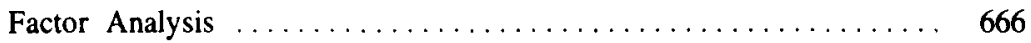

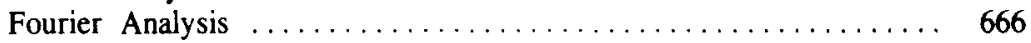

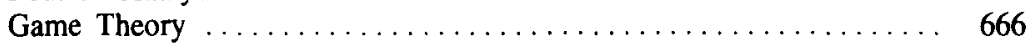

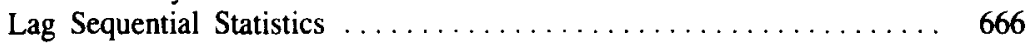

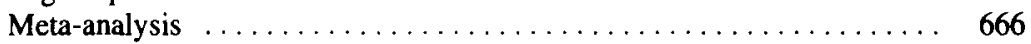

Nonparametric Statistics $\ldots \ldots \ldots \ldots \ldots \ldots \ldots \ldots \ldots \ldots \ldots \ldots \ldots 66 \ldots \ldots$

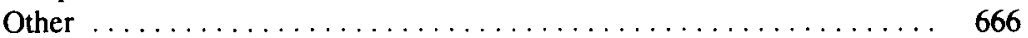

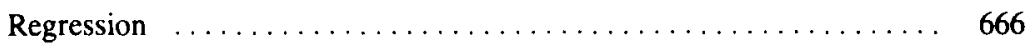

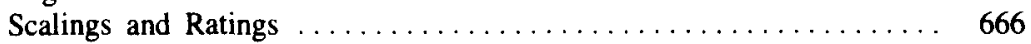

Statistical Packages..$\ldots \ldots \ldots \ldots \ldots \ldots \ldots \ldots \ldots \ldots \ldots \ldots 67$

(See also Software, Evaluation and Comparison)

Structural Equation Modeling ...................... 667 
Stimulus Generation and Selection

(See also Experiment Design)

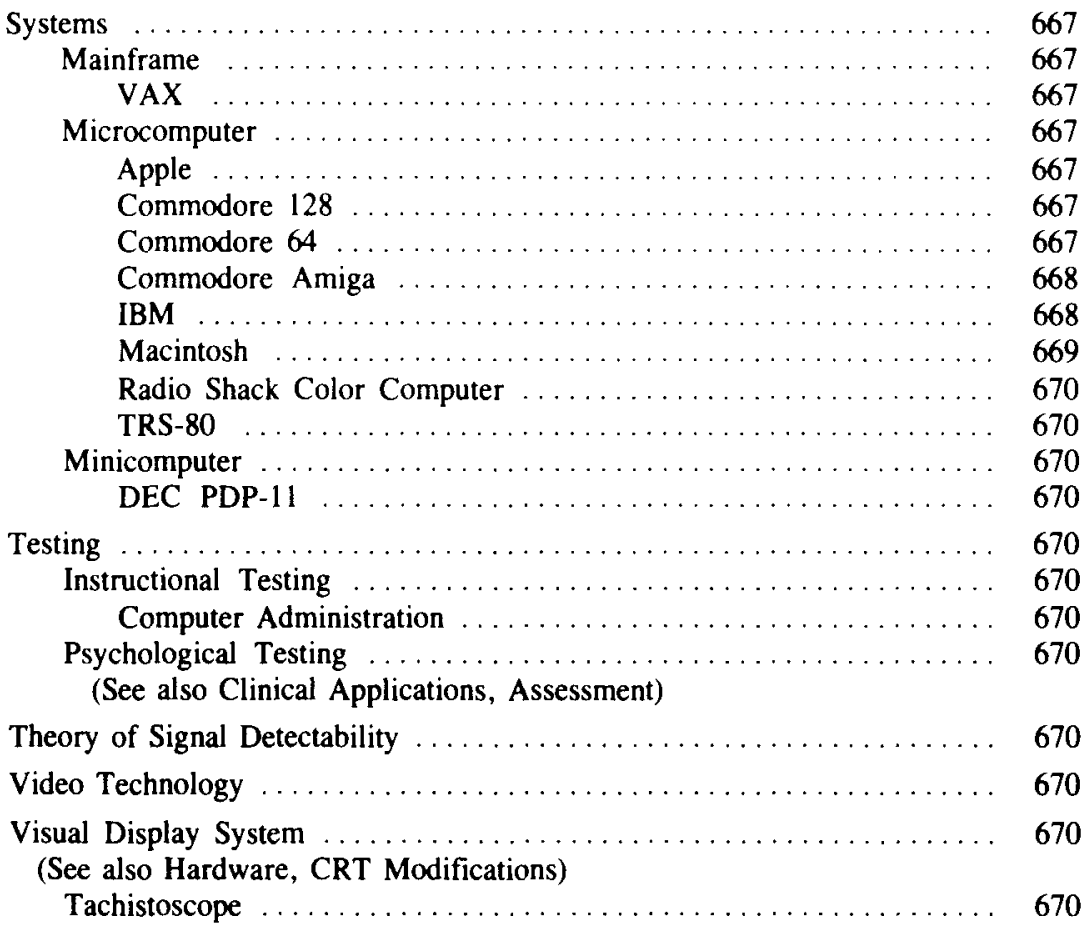




\section{Computer Technology Index}

\section{ARTIFICIAL INTELLIGENCE AND APPLICATIONS}

McClelland, J. L., \& Rumelhart, D. E. (1988). A simulation based tutorial system for exploring parallel distributed processing. 20, 263-275.

Munro, P. W., \& ANderson, J. A. (1988). Tools for the connectionist modeling: The dynamical systems methodology. 20 , 276-281.

SCHNEIDER, W. (1988). Sensitivity analysis in connectionist modeling. 20, 282-288.

\section{Expert Systems}

Jones, J. A., Miller, B. O., \& Scarborough, D. L. (1988). A rule-based expert system for music perception. 20, 255-263.

LACHMAN, R. (1989). Expert systems: A cognitive science perspective. 21, 195-204.

\section{Neural Nets}

Bremner, F. J., Yost, M., \& Nasman, V. T. (1989). Statistical analysis of fuzzy-set data from neuronal networks. 21, 209-212.

LEVINE, D. S. (1989). Neural network principles for theoretical psychology. 21, 213-224.

Maki, W. S., \& Abunawass, A. M. (1989). A neural network simluator for supercomputers. 21, 225-239.

\section{CLINICAL APPLICATIONS}

Eiler, J. M., Nelson, W. W., Jensen, C. C., \& Johnson, S. P. (1989). Automated data collection using bar code. 21, 53-58.

Mitterer, J., \& ADAMS-WebBer, J. (1988). OMNIGRID: A general repertory grid design, administration, and analysis program. 20, 359-360.

Swanson, J. M., Nuechterlein, K., Asarnow, R., Taylor, E., Hunt, R., Shaywitz, B., Shaywitz, S., Potkin, S., Early, T., Cloninger, C. R., \& Posner, M. (1989). Use of a common software system for collaborative clinical research on attentional processes in schizophrenia and ADHD. 21, 250-254.

Zimmerman, D. P. (1989). Electronic language: A study of word processing by emotionally disturbed children and adolescents in residential treatments. 21, 181-186.

\section{Assessment}

Ostrander, L. E., Kandel, G. L., Jenkins, P. L., \& Simon, J. W. (1989). A preferential looking clinical acuity test: Improvements in implemented microcomputer control. 21, $421-425$.

Stout, C. E. (1988). Personal computer software for teaching differential psychodiagnostics. 20, 106-107.

Stout, C. E., \& Scheramic, M. (1989). Innovative uses of existing software in the teaching of psychodiagnostics. 21, $187-188$

\section{COMPUTER CONFERENCING}

Anderson, M., \& Hornby, P. (1989). COMPsych: A description and progress report. 21, 205-208.
Anderson, M., Hornby, P., \& BozaK, D. (1988). COMPsych: A computerized software information system. 20, 243-245.

\section{COMPUTER RANDOMIZATION TECHNIQUES}

LORDAHL, D. S. (1988). Repairing the Microsoft BASIC RND function. 20, 221-223.

\section{COMPUTER TIMING}

Brysbaert, M., Bovens, N., D'Ydewalle, G., \&an CalSTER, J. (1989). Turbo Pascal timing routines for the IBM microcomputer family. 21, 73-83.

Crosbie, J. (1989). A simple Turbo Pascal 4.0 program for millisecond timing on the IBM PC/XT/AT. 21, 408-413.

Dlhopolsky, J. G. (1988). C language functions for millisecond timing on the IBM PC. 20, 560-565.

EMERSON, P. L. (1988). The best crude timer for MS-DOS implementations of C. $20,583-584$.

Emerson, P. L. (1988). TIMEX: A simple IBM AT C language timer with extended resolution. 20, 566-572.

Emerson, P. L. (1988). Using serial interfaces and the C language for real-time experiments. 20, 330-336.

GranaAs, M. M. (1989). TIMEX2: A modified C-language timer for PC-AT class machines. 21, 619-622.

Graves, R., \& BradLEY, R. (1988). More on millisceond timing and tachistoscope applications for the IBM PC. 20, 408-412.

HeathCote, A. (1988). Screen control and timing routines for the IBM microcomputer family using a high-level language. 20, 289-297.

Kieley, J. M., \& Higgins, T. S. (1989). Precision timing options for the Apple Macintosh family of computers. 21, 259-264.

Merbitz, C., Grip, J., \& Marqui, H. P. (1988). A jiffy clock for the Apple IIc, II + , and IIe with a mouse. 20, 362 .

Westall, R. F., Perkey, M. N., \& Chute, D. L. (1989). Millisecond timing on the Apple Macintosh: Updating Drexel's MilliTimer. 21, 540-547.

\section{COMPUTER UTILITIES}

Data Transfer

Pieper, W., \& LaChNIT, H: (1989). C64-to-PC: Transmitting data from a Commodore C64 to IBM-compatible PC's. 21, 653.

\section{COMPUTERS}

\section{General Use in Psychology}

Anderson, M., Hornby, P., \& BozaK, D. (1988). COMPsych: A computerized software information system. 20, 243-245. Anderson, M., \& Hornby, P. (1989). COMPsych: A description and progress report. 21, 205-208.

LeHMAN, R. S. (1988). The languages we use. 20, 236-242. Null, C. H. (1988). Science, politics, and computers. 20, 73-80.

\section{Psychological Theory}

LEvine, D. S. (1989). Neural network principles for theoretical psychology. 21, 213-224. 


\section{Selection and Maintenance}

SCHNeider, W. (1989). Computer viruses: What they are, how they work, how they might get you, and how to control them in academic institutions. 21, 334-340.

\section{COMPUTERS IN EDUCATION}

BUTLER, D. L. (1988). A critical evaluation of software for experiment development in research and teaching. 20, 218-220.

Castellan, N. J. (1988). Comments on the applications of microcomputers in teaching. 20, 193-196.

Gallo, P., Julian, D., \& Wideman, G. (1989). Introduction to computer use: Curriculum development. 21, 151-154.

HeWETt, T. T. (1989). The Drexel Disk: Hypertext-based instructional software as a tool for the exploration of a constrained knowledge system. 21, 316-325.

LeE-Sammons, W. H., \& Wollen, K. A. (1989). Computerized practice tests and effects on in-class exams. 21, 189-194.

Stout, C. E., \& SCheramic, M. (1989). Innovative uses of existing software in the teaching of psychodiagnostics. 21, 187-188.

\section{CAI}

Stout, C. E. (1988). Personal computer software for teaching differential psychodiagnostics. 20, 106-107.

Wise, B., Olson, R., Anstett, M., Andrews, L., Teruak, M., SCHNeIder, V., Kostuch, J., \& KRIHo, L. (1989). Implementing a long-term computerized remedial reading program with synthetic speech feedback: Hardware, software, and real-world issues. 21, 173-180.

\section{Mathematics}

BradLey, D. R. (1989). Computer simulation with DATASIM. 21, 99-112.

Galla, J. P. (1989). BASIC statistics for IBM computers: An integrated instructional statistical package. 21, 481.

ROGERS, R. L. (1989). Using the microcomputer as a visual aid in the statistics classroom. 21, 96-98.

VerCruYsSen, M., \& EDWARDS, J. C. (1988). ANOVA/TT: Analysis of variance teaching template for Lotus 1-2-3. 20, 349-354.

\section{Courseware}

EAmon, D. B. (1988). Problems with evaluation of courseware for instruction in psychology. 20, 178-179.

\section{Student Laboratory}

Batson, J. D., \& Einstein, G. O. (1989). Developing a microcomputer laboratory at a small liberal arts college. 21, 139-141.

BUTLER, D. L. (1988). Selection of software in the instructional laboratory. 20, 175-177.

Conn, G., Stafiniak, P., DiPasquale, M. C., \& Harper, L. (1988). Effects of teaching an introductory psychology laboratory using a computerized research tool. 20, 184-187.

CushiNG, S. (1989). Minds and machines: Computers and cognition in a liberal arts context. 21, 155-159.

GoolkasIAN, P. (1989). Computerized laboratories for psychology instruction: How successful are they? 21, 148-150.

Hatten, J. L., \& Hatten, A. D. (1989). Implementing an undergraduate research apprenticeship with the Macintosh computer. 21, 142-147.

HEWETT, T. T. (1988). Some observations on applications of microcomputers in teaching. 20, 191-192.

HoRnBy, P.. \& ANDERSON, M. (1988). Using computers in introductory psychology. 20, 180-183.

Leith, C. R., Hamm, H. D., Duncanson, C., Senical, T. (1988). A computer-driven undergraduate laboratory curriculum and related support logistics. 20, 188-190.

MCAllister, H. A. (1989). Funding an undergraduate microcomputer laboratory: A case study. 21, 134-138.

Peterson, S. B. (1989). A microcomputer lab for psychology based on a hierarchical learning model. 21, 130-133.

RANSDELl, S., \& Levy, C. M. (1989). A flexible and interactive software package for a laboratory in cognition and perception. 21, 160-162.

SARGENT, D. M. (1989). Use of on-line computers in experimental psychology: Hardware considerations. 21, 163-165.

SCHNEIDER, W. (1989). Enhancing a standard experimental delivery system (MEL) for advanced psychological experimentation. 21, 240-244.

St. JAmES, J. D. (1989). The MEL Library in the undergraduate research methods course. 21, 245-247.

VIEIRA, A. A. (1989). Using MEL in a networked classroom. 21, 248-249.

\section{EEG/EMG/ECG}

BARo, J. A., \& LehmKuhle, S. (1988). A software system for recording and analyzing transient evoked potential data with an Apple Ile computer. 20, 515-516.

KaPLAN, H. L., \& Noldy, N. E. (1989). A general framework for defining evoked potential paradigms. 21, 285-293.

Yost, M., Bremner, F. J., \& NASMAN, V. T. (1988). Using three-dimensional graphics in neuropsychological hypothesis testing. 20, 108-112.

\section{EXPERIMENT DESIGN}

Adedi, J., \& ShAVELSON, R. (1988). FRACTION: A computer program for fractional factorial design. 20, 58-59.

Carver, C. S., Dunham, R. G., Spitzer, M. W., \& DelGADO, L. M. (1988). A tracking program to schedule subjects across multipanel longitudinal research. 20, 576-578.

Greene, S., Ratcliff, R., \& McKoon, G. (1988). A flexible programming language for generating stimulus lists for cognitive psychology experiments. 20, 119-128.

Strube, M. J (1988). A BASIC program for the generation of Latin squares. 20, 508-509.

\section{GRAPHICS}

AlDRIDGE, J. W., \& FLORES, S. A. (1988). Random figures and mirror images with variable complexity, size, and orientation in Applesoft BASIC. 20, 313-316.

Brooks, J. O., III, \& BiEBER, L. L. (1988). Digitized nonobjects for use with the Apple Macintosh computer. 20, 433-434.

Palmer, C. (1989). Computer graphics in music performance research. 21, 265-270.

Yost, M., Bremner, F. J., \& Nasman, V. T. (1988). Using three-dimensional graphics in neuropsychological hypothesis testing. 20, 108-112.

Yost, M., Gindler, L., \& Bremner, F. J. (1988). Multivariate statistics and three-dimensional graphics. 20, 113-117. 


\section{Animation of Graphics}

BeNTE, G. (1989). Facilities for the graphical computer simulation of head and body movements. 21, 455-462.

\section{Software}

Tanner, P. P., Jolicoeur, P., Cowan, W. B., Booth, K., \& Fishman, F. (1989). Antialiasing: A technique for smoothing jagged lines on a computer graphics image-an implementation on the Amiga. 21, 59-66.

\section{HARDWARE}

\section{Evaluation and Comparison}

Popper, R., Dragshaek, H., Siegel, S. F., \& Hirsch, E. (1988). Use of pocket computers for self-administration of cognitive tests in the field. 20, 481-484.

\section{CRT Modifications}

Maloney, L. T., \& KoH, K. (1988). A method for calibrating the spatial coordinates of a visual display to high accuracy. 20, 372-389.

\section{Printers/Plotters}

Garcí-Pérez, M. A. (1989). 123 halftone patterns for printing gray-level images on a laser printer. 21, 24-30.

\section{HUMAN FACTORS}

\section{Human-Computer Interaction}

GetTys, C. F., \& Berglan, L. (1989). Laboratory MicroStar: A data-logging word processor for research on word processors. 21, 484-486.

HEWETT, T. T. (1988). The electronic spreadsheet as a professional productivity tool. 20, 231-235.

\section{HYPERMEDIA}

Gray, S. H., \& Shasha, D. (1989). To link or not to link? Empirical guidance for the design of nonlinear text systems. 21, 326-333.

Hewett, T. T. (1989). The Drexel Disk: Hypertext-based instructional software as a tool for the exploration of a constrained knowledge system. 21, 316-325.

\section{HyperCard}

Geisler-Brenstein, E., \& Brenstein, R. J. (1989). The potential of HyperCard for psychological research and instruction: A general discussion and description of two research applications. 21, 307-311.

Martin, T. A., \& Wilcox, K. L. (1989). HyperCard administration of a block-design task. 21, 312-315.

NASON, S., \& ZABRUCKY, K. (1988). A program for comprehension monitoring of text using HyperCard for the Macintosh. 20, 499-502.

\section{IMAGE PROCESSING}

García-PÉrez, M. A. (1988). HDC: A subroutine library for image processing using Burt's hierarchical discrete correlation. 20, 317-329.

\section{INTERFACE}

D'ANDREA, J. A., \& KNEPTON, J. (1988). Construction and implementation of a low-cost electronic experiment control interface. 20, 97-99.

EMERSON, P. L. (1988). Using serial interfaces and the C language for real-time experiments. 20, 330-336.

FRANKS, I. M. (1988). A method for investigating the sequential ordering of simple movement patterns: An IBM-based application using the Tecmar Labmaster. 20, 298-306.

Lavond, D. G., \& Steinmetz, J. E. (1989). An inexpensive interface for the IBM PC/XT and compatibles. 21, 435-440.

\section{LABORATORY CONTROL PROGRAM}

CONLEY, J. (1989). An experiment control system for the Amiga microcomputer. 21, 391-393.

D'ANDREA, J. A., \& KNEPTON, J. (1988). Construction and implementation of a low-cost electronic experiment control interface. 20, 97-99.

Edgell, S. E., \& HeRTEl, S. A. (1989). Running laboratory experiments using the RSX operating system and FORTRAN on the PDP-11. 21, 303-306.

Palya, W. L. (1988). An introduction to the Walter/Palya controller and ECBASIC. 20, 81-87.

Pevey, M. E. (1988). Using an IBM PC to network Walter/Palya experiment controllers. 20, 100-103.

SCHNEIDER, W. (1989). Enhancing a standard experimental delivery system (MEL) for advanced psychological experimentation. 21, 240-244.

SCHNEIDER, W. (1988). Micro Experimental Laboratory: An integrated system for IBM PC compatibles. 20, 206-217.

Tatham, T. A., \& Zurn, K. R. (1989). The MED-PC experimental apparatus programming system. 21, 294-302.

WALTER, D. E. (1988). The Walter/Palya experiment controller users' group meeting and help session. 20, 104-105.

Weisman, R., \& Palya, W. (1988). Development and operating environments for a network of Walter/Palya experiment controllers on the Macintosh computer. 20, 93-96.

\section{LANGUAGE}

APL

ANSON, J. (1988). ROBREG: An APL procedure for fitting robust regression lines using Huber's M-estimate. 20, 579-582.

BERRY, K. J. (1989). An APL function for the asymptotic test of significance for Goodman and Kruskal's gamma statistic. 21, 473-476.

BerRy, K. J., \& Mielke, P. W., JR. (1988). APL approximations for common statistical critical values. 20, 339-342.

Brennan, J. M., NiTz, L. H., \& Daly, J. E. (1988). An APL program for measures of association for ordinal variables. 20 , 429-431.

Sakurai, M. M., \& Brennan, J. M. (1989). Computing the Harsanyi function $H(S)$ for $n$-person cooperative transferable utility normal form games. 21, 535-539.

Sakurai, M. M., \& Brennan, J. M. (1988). Computing the von Newmann-Morgenstern characteristic function $v(S)$ for cooperative $n$-person transferable utility normal form games. 20, 367-371. 


\section{Assembler/Machine Language}

Baro, J. A., \& Lehmkuhle, S. (1988). A software system for recording and analyzing transient evoked potential data with an Apple Ile computer. 20, 515-51.

Biggs, T. C., Pulham, D., \& Bleasdale, F. A. (1988). Apple slide tachistoscope. 20, 49-53.

EAmON, D. B. (1988). Enhancing Applesoft using ampersand routines. 20, 224-230.

Segalowitz, S. J. (1988). IBM PC tachistoscope: II. Assembly language subroutines. 20,432 .

Wright, R. D., \& DAwson, M. R. W. (1988). Using hardware interrupts for timing visual displays and reaction-time key interfacing on the Commodore 64. 20, 41-48.

Lavond, D. G., \& Steinmetz, J. E. (1989). An inexpensive interface for the IBM PC/XT and compatibles. 21, 435-440.

\section{BASIC}

Adedi, J., \& Shavelson, R. (1988). FRACTION: A computer program for fractional factorial design. 20, 58-59.

Aldridge, J. W., \& Flores, S. A. (1988). Random figures and mirror images with variable complexity, size, and orientation in Applesoft BASIC. 20, 313-316.

Baro, J. A., \& LehmKuhle, S. (1988). A software system for recording and analyzing transient evoked potential data with an Apple Ile computer. 20, 515-51.

Beins, B. C. (1989). An Applesoft BASIC program for the $G$-statistic: An alternative to the chi-square test. 21, 627-629.

BENTE, G. (1989). Facilities for the graphical computer simulation of head and body movements. 21, 455-462.

Biggs, T. C., Pulham, D., \& Bleasdale, F. A. (1988). Apple slide tachistoscope. 20, 49-53.

Brophy, A. (1988). A BASIC program for the multistage Bonferroni procedure for many correlations. 20, 416-418.

Brophy, A. L., \& Wood, D. L. (1989). Algorithms for fast and precise computation of the normal integral. 21, 447-454.

Carver, C. S., Dunham, R. G., Spitzer, M. W., \& DelGADO, L. M. (1988). A tracking program to schedule subjects across multipanel longitudinal research. 20, 576-578.

Cooper, L. D., Garica, R., \& Gibbon, J. (1988). The labtop Macintosh: An interface and communications software for experiment control of animal learning research. $20,88-92$.

D'ANDREA, J. A., \& KNEPTON, J. (1988). Construction and implementation of a low-cost electronic experiment control interface. 20, 97-99.

DAwson, D. L. (1988). A BASIC factorial analysis of covariance program for three microcomputer families. 20, 419.

Dawson, M. R. W. (1988). Fitting the ex-Gaussian equation to reaction time distributions. 20, 54-57.

EAMON, D. B. (1988). Enhancing Applesoft using ampersand routines. 20, 224-230.

EMERSON, P. L. (1988). FISHTAIL: Practical $F$ integration on small computers in BASIC and C. 20, 65-69.

Ergener, D., \& Wellens, A. R. (1989). DataVision: A computer-based system for generating and reading digital information accompanying video images on videotape. 21 , $401-407$.

GALLA, J. P. (1989). BASIC statistics for IBM computers: An integrated instructional statistical package. 21, 481.

Graves, R., \& Bradley, R. (1988). More on millisecond timing and tachistoscope applications for the IBM PC. 20, 408-412.
Hodge, M. H., \& Pittenger, D. J. (1988). More statistical programs for Commodore computers. 20, 427-428.

Krauss, R. M. , Morrel-Samuels, P., \& Hochberg, J. (1988). VIDEOLOGGER: A computerized multichannel event recorder for analyzing videotapes. 20, 37-40.

Latimer, C. R. (1988). Eye-movement data: Cumulative fixation time and cluster analysis. 20, 437-470.

LORDAHL, D. S. (1988). Repairing the Microsoft BASIC RND function. 20, 221-223.

MALCOLM, D. S. (1989). A BASIC program for exploratory data analysis. 21, 463-464.

Marshall-Goodell, B., Frei, L., \& Gormezano, I. (1989). A personal computer programmable sine-wave generator. 21 , 431-434.

Merbitz, C., Grip, J., \& Marqui, H. P. (1988). A jiffy clock for the Apple IIc, II +, and Ile with a mouse. 20, 362 .

Mitterer, J., \& ADAMS-Webber, J. (1988). OMNIGRID: A general repertory grid design, administration, and analysis program. 20, 359-360.

Ransdell, S., \& Levy, C. M. (1989). A flexible and interactive software package for a laboratory in cognition and perception. 21, 160-162.

RoSE, D. (1988). ZSCORE: A program for the accurate calculation of $z$ scores, $d^{\prime}$, and $\beta$. 20, 63-64.

Rossi, J. S. (1988). ONEWAY: A BASIC program for computing ANOVA from group summary statistics. 20, 347-348.

SChlottmanN, R. S. (1989). A BASIC program for classification analysis using proportional and maximum chance estimates of prior probabilities. 21, 636-638.

Stout, C. E. (1988). Personal computer software for teaching differential psychodiagnostics. 20, 106-107.

Strube, M. J (1988). A BASIC program for the generation of Latin squares. 20, 508-509.

Strube, M. J (1988). Three computer-automated social psychology laboratory tasks. 20, 557-559.

Strube, M. J (1988). Calculation of significance regions for multiple predictors by the Johnson-Neyman technique. 20 , 510-512.

Symons, D. K., Wright, R. D., \& Moran, G. (1988). Computing lag sequential statistics on dyadic time interval data: The TLAG program. 20, 343-346.

TuRner, S. L., \& MACLEOD, C. M. (1988). SLIDE MAKER: A BASIC program to create 35 -mm slides of verbal materials. 20, 355-358.

VoKeY, J. R. (1989). Matching factor structures using orthogonal rotation to congruence. $21,84-85$.

W ALCZYK, J. J., \& RoYeR, J. M. (1989). A program for constructing SVT tests: An alternative way of assessing text comprehension. 21, 369-370.

WALTER, D. E. (1988). The Walter/Palya experiment controller users' group meeting and help session. 20, 104-105.

Watkins, M. W., \& Kush, J. C. (1988). Micro-CONGRU: A microcomputer program for measuring levels of overall and partial congruence among multiple observers on nominal scales. 20, 513-514.

Weisman, R., \& Palya, W. (1988). Development and operating environments for a network of Walter/Palya experiment controllers on the Macintosh computer. 20, 93-96.

WolACH, A. H. (1988). ANOVA, Latin square, and ANCOVA for IBM-compatible microcomputer systems. 20, 585-586.

Wolach, A. H., \& McHale, M. A. (1988). Orthogonal comparisons. 20, 337. 
WooD, D. L. (1988). Advanced algorithms for the numerical integration of $t .20,60-62$.

\section{C}

DLhopolsky, J. G. (1988). C language functions for millisecond timing on the IBM PC. 20, 560-565.

Dlhopolsky, J. G. (1989). Synchronizing stimulus displays with millisecond timer software for the IBM PC. 21, 441-446.

Emerson, P. L. (1988). Compact $C$ language Fourier analysis on small computers. 20, 423-426.

EMERSON, P. L. (1988). FISHTAIL: Practical $F$ integration on small computers in BASIC and C. 20, 65-69.

EMERSON, P. L. (1989). NEWSART: Negative binomial weighted spectral analysis in real time. 21, 353-368.

EMERSON, P. L. (1988). The best crude timer for MS-DOS implementations of C. 20, 583-584.

Emerson, P. L. (1988). TIMEX: A simple IBM AT C language timer with extended resolution. 20, 566-572.

EMERSon, P. L. (1988). Using serial interfaces and the $C$ language for real-time experiments. 20, 330-336.

GranaAs, M. M. (1989). TIMEX2: A modified C-language timer for PC-AT class machines. 21, 619-622.

Landy, M. S., Manovich, L. Z., \& STetren, G. D. (1989). All about EVE: The early vision emulation software. 21, 491-501

MarKs, W., \& Greer, J. B. (1989). A set of color-graphics routines for studying perceptual learning on the IBM-PC. 21 , $574-578$

May, R. B., Masson, E. J., \& Hunter, M. A. (1989). Randomization tests: Viable alternatives to normal curve tests 21, 482-483.

McConkie, G. W., Scouten, C. W., Bryant, P. K., \& WiLson, J. (1988). A microcomputer-based software package for eye monitoring research. 20, 142-149.

Redmond, R. T., \& Gasen, J. B. (1988). PAST: Viewing the programming process. 20, 503-507.

Tanner, P. P., Jolicoeur, P., Cowan, W. B., Booth, K., \& Fishman, F. (1989). Antialiasing: A technique for smoothing jagged lines on a computer graphics image-an implementation on the Amiga. 21, 59-66.

WILsON, M. (1988). MRC Psycholinguistic Database: Machineusable dictionary, version 2.00. 20, 6-10.

\section{FORTH}

Lavond, D. G., \& Steinmetz, J. E. (1989). An inexpensive interface for the IBM PC/XT and compatibles. 21, 435-440.

\section{FORTRAN}

Adedi, J., \& Shavelson, R. (1988). FRACTION: A computer program for fractional factorial design, 20, 58-59.

Conley, J. (1989). An experiment control system for the Amiga microcomputer. 21, 391-393.

DUNLAP, W. P. (1989). A program for exact power of the $2 \times 2$ chi-square. 21, 645-646.

DunlaP, W. P., \& Kemery, E. R. (1988). Biserial and pointbiserial correlation with correction for nonoptimal dichotomies. 20, 420-422.

EdGell, S. E., \& HerTel, S. A. (1989). Running laboratory experiments using the RSX operating system and FORTRAN on the PDP-11. 21, 303-306.

García-PÉrez, M. A. (1988). HDC: A subroutine library for image processing using Burt's hierarchical discrete correlation. 20, 317-329.

KINGMA, J., \& TAERUM, T. (1988). A FORTRAN 77 program for a nonparametric item response model: The Mokken scale analysis. 20, 471-480.

KRIEG, E. F., JR. (1988). A FORTRAN 77 program for the runs test. 20, 361 .

Longman, R. S., Cota, A. A., Holden, R. R., \& FeKKen, G. C. (1989). PAM: A double-precision FORTRAN routine for the parallel analysis method in principal components analysis. 21, 477-480.

MaKi, W. S., \& ABUnawass, A. M. (1989). A neural network simluator for supercomputers. 21, 225-239.

Martin, S. A., \& ToOthaKer, L. E. (1989). PERITZ: A FORTRAN program for performing multiple comparisons of means using the Peritz Q method. 21, 465-472.

Silver, N. C., \& Hollungsworth, S. C. (1989). A FORTRAN 77 program for averaging correlation coefficients. 21, 647-650.

Stanislaw, H. (1989). Lookup tables for linear trajectories through color space. 21, 502-524.

\section{LISP}

LiebHABER, M. J. (1988). A computer model of inflection learning. 20, 246-254.

\section{PASCAL}

Barnes, S., \& BuRKe, R. S. (1988). What is Apple-Psych? 20, $150-154$

Brysbaert, M., Bovens, N., D'Ydewalle, G., \& Van CalSTER, J. (1989). Turbo Pascal timing routines for the IBM microcomputer family. 21, 73-83.

Crosbie, J. (1989). A simple Turbo Pascal 4.0 program for millisecond timing on the IBM PC/XT/AT. 21, 408-413.

FranKs, I. M. (1988). A method for investigating the sequential ordering of simple movement patterns: An IBM-based application using the Tecmar Labmaster. 20, 298-306.

García-Pérez, M. A. (1989). 123 halftone patterns for printing gray-level images on a laser printer. 21, 24-30.

GetTYs, C. F., \& Berglan, L. (1989). Laboratory MicroStar: A data-logging word processor for research on word processors. 21, 484-486.

HEATHCOTE, A. (1988). Screen control and timing routines for the IBM microcomputer family using a high-level language. 20, 289-297.

Jones, J. A., Miller, B. O., \& SCarborough, D. L. (1988). A rule-based expert system for music perception. 20, 255-263.

Jorgensen, P., Rucker, T. J., \& Reynolds, J. H. (1989). A Pascal function for presenting MacPaint files on the Macintosh. 21, 415-419.

Kahana, M. J., \& DetTerman, D. K. (1989). ABC: A program to convert PSYCHLIT CD-ROM abstracts into APAstyle bibliographies. 21, 414 .

Lachnit, H., SChNedier, R. L., LiPP, O. V., \& Kimmel, H. D. (1988). RWMODEL: A program in Turbo Pascal for simulating predictions based on the Rescorla-Wagner model of classical conditioning. 20, 413-415.

LoCK, S., \& LeONG, C. K. (1989). Program library for DECtalk text-to-speech system. 21, 394-400.

Michener, H. A., Abrams, C. L., \& Ebert, R. F. (1989). MAUA 145: A PASCAL program for multi-attribute utility analysis. 21, 651-652. 
Mundt, J. C. (1989). Computer-based preference models for generic multidimensional problem sets. 21, 121-124.

OsGOOD, G. (1988). Generalizing the Apple-Psych system. 20, 155-157.

SChWARZER, R. (1988). Meta-analysis programs. 20, 338.

Stoddard, P. K., \& Loftus, G. R. (1988). An IBM XTcompatible, computer-based, slide-projector laboratory. $\mathbf{2 0}$, 541-551.

TAtham, T. A., \& ZuRn, K. R. (1989). The MED-PC experimental apparatus programming system. 21, 294-302.

\section{MOTOR BEHAVIOR}

Barnes, H. J., Vaughan, J., Jorgensen, M. J., \& RosenBAUM, D. A. (1989). A low-cost method for digitizing videotaped continuous movements on the Macintosh. 21, 255-258.

Bente, G. (1989). Facilities for the graphical computer simulation of head and body movements. 21, 455-462.

Franks, I. M. (1988). A method for investigating the sequential ordering of simple movement patterns: An IBM-based application using the Tecmar Labmaster. 20, 298-306.

Ouvo, R. F., \& Thом Pson, M. C. (1988). Monitoring animals' movements using digitized video images. 20, 485-490.

Pear, J. J., Silva, F. J., \& Kincaid, K. M. (1989). Threedimensional spatiotemporal imaging of movement patterns: Another step toward analyzing the continuity of behavior. 21, 568-573.

Seeley, R. J., \& Brozoski, T. J. (1989). Measurement and quantification of stereotypy in freely behaving subjects: An information analysis. 21, 271-274.

Silverman, R. W., Chang, A. S., \& Russell, R. W. (1988). Measurement of activity in small animals using a microcomputer-controlled system. 20, 537-540.

\section{NETWORKING AND TIMESHARING}

D'ANDREA, J. A., \& KNEPTON, J. (1988). Construction and implementation of a low-cost electronic experiment control interface. 20, 97-99.

PALYA, W. L. (1988). An introduction to the Walter/Palya controller and ECBASIC. 20, 81-87.

Pevey, M. E. (1988). Using an IBM PC to network Walter/ Palya experiment controllers. 20, 100-103.

VIEIRA, A. A. (1989). Using MEL in a networked classroom. 21, 248-249.

WALTER, D. E. (1988). The Walter/Palya experiment controller users' group meeting and help session. 20, 104-105.

Weisman, R., \& Palya, W. (1988). Development and operating environments for a network of Walter/Palya experiment controllers on the Macintosh computer. 20, 93-96.

\section{OBSERVATIONAL METHODS}

\section{Recorders}

Eiler, J. M., Nelson, W. W., Jensen, C. C., \& Johnson, S. P. (1989). Automated data collection using bar code. 21, 53-58.

\section{OPERATING SYSTEMS}

\section{UNIX}

Landy, M. S., Manovich, L. Z., \& Stetten, G. D. (1989). All about EVE: The early vision emulation software. 21, 491-501.

\section{PROFESSIONAL PRODUCTIVITY AIDS}

Hewett, T. T. (1988). The electronic spreadsheet as a professional productivity tool. 20, 231-235.

\section{Reference/Reprint Management}

Kahana, M. J., \& Detterman, D. K. (1989). ABC: A program to convert PSYCHLIT CD-ROM abstracts into APAstyle bibliographies. 21,414 .

\section{PROGRAMMING}

Lehman, R. S. (1988). The languages we use. 20, 236-242. REDmond, R. T., \& GASEN, J. B. (1988). PAST: Viewing the programming process. 20, 503-507.

\section{Computer Languages for Psychology}

TAtham, T. A., \& ZURN, K. R. (1989). The MED-PC experimental apparatus programming system. 21, 294-302.

\section{Tips and Techniques}

Eamon, D. B. (1988). Enhancing Applesoft using ampersand routines. 20, 224-230.

\section{RESEARCH APPLICATIONS}

\section{Animal Behavior}

Cooper, L. D., Garica, R., \& Gibbon, J. (1988). The labtop Macintosh: An interface and communications software for experiment control of animal learning research. 20, 88-92.

Olivo, R. F., \& Thompson, M. C. (1988). Monitoring animals' movements using digitized video images. 20, 485-490.

Pear, J. J., Silva, F. J., \& Kincaid, K. M. (1989). Threedimensional spatiotemporal imaging of movement patterns: Another step toward analyzing the continuity of behavior. 21, 568-573.

SeEley, R. J., \& Brozoski, T. J. (1989). Measurement and quantification of stereotypy in freely behaving subjects: An information analysis. 21, 271-274.

Silverman, R. W., Chang, A. S., \& Russell, R. W. (1988). A microcomputer-controlled system for measuring reactivity in small animals. 20, $495-498$

Silverman, R. W., Chang, A. S., \& Russell, R. W. (1988). Measurement of activity in small animals using a microcomputercontrolled system. 20, 537-540.

Washburn, D. A., Hopkins, W. D., \& Rumbaugh, D. M. (1989). Automation of learning-set testing: The video-task paradigm. 21, 281-284.

\section{Biopsychology/Psychophysiology}

KaPlan, H. L., \& Noldy, N. E. (1989). A general framework for defining evoked potential paradigms. 21, 285-293.

\section{Cognition and Memory}

BARnes, S., \& BURKe, R. S. (1988). What is Apple-Psych? 20, 150-154.

Conley, J. (1989). An experiment control system for the Amiga microcomputer. 21, 391-393.

Greene, S., Ratcliff, R., \& MCKoon, G. (1988). A flexible programming language for generating stimulus lists for cognitive psychology experiments. 20, 119-128. 
Popper, R., Dragsbaek, H., Siegel, S. F., \& Hirsch, E. (1988). Use of pocket computers for self-administration of cognitive tests in the field. $20,481-484$.

\section{Conditioning}

Cooper, L. D., Garica, R., \& Gibbon, J. (1988). The labtop Macintosh: An interface and communications software for experiment control of animal learning research. 20, 88-92.

Emerson, P. L. (1988). Using serial interfaces and the $C$ language for real-time experiments. 20, 330-336.

GENOVESE, R. F. (1988). A strategy for microcomputer-controlled measurement of responses in the behavioral laboratory. 20, 1-5.

Lavond, D. G., \& Steinmetz, J. E. (1989). An inexpensive interface for the IBM PC/XT and compatibles. 21, 435-440.

Pear, J. J., Silva, F. J., \& Kincaid, K. M. (1989). Threedimensional spatiotemporal imaging of movement patterns: Another step toward analyzing the continuity of behavior. 21, 568-573.

TATham, T. A., \& ZURN, K. R. (1989). The MED-PC experimental apparatus programming system. 21, 294-302.

Washburn, D. A., Hopkins, W. D., \& Rumbaugh, D. M. (1989). Automation of learning-set testing: The video-task paradigm. 21, 281-284.

\section{Eye Movement Measurements}

Latimer, C. R. (1988). Eye-movement data: Cumulative fixation time and cluster analysis. 20, 437-470.

McConkie, G. W., Scouten, C. W., Bryant, P. K., \& WiLSON, J. (1988). A microcomputer-based software package for eye monitoring research. 20, 142-149.

TyRRELl, R. A., \& OWens, D. A. (1988). A rapid technique to assess the resting states of the eyes and other threshold phenomena: The Modified Binary Search (MOBS). 20, 137-141.

\section{General}

Algarabel, S., Sanmartin, J., \& Ahuir, F. (1989). A voiceactivated key for the Apple Macintosh computer. 21, 67-72.

Barnes, S., \& Burke, R. S. (1988). What is Apple-Psych? 20, 150-154.

Boles, D. B. (1988). Voice recognition with the Apple-Psych system. 20, 158-163.

Brooks, J. O., III, \& BIEBER, L. L. (1988). Digitized nonobjects for use with the Apple Macintosh computer. 20, 433-434.

Butler, D. L. (1988). A critical evaluation of software for experiment development in research and teaching. 20, 218-220.

Costin, D. (1988). MacLab: A Macintosh system for psychology labs. 20, 197-200.

Eiler, J. M., Nelson, W. W., Jensen, C. C., \& Johnson, S. P. (1989). Automated data collection using bar code. 21, 53-58.

HeathCote, A. (1988). Screen control and timing routines for the IBM microcomputer family using a high-level language. 20, 289-297.

OsGOOD, G. (1988). Generalizing the Apple-Psych system. 20, 155-157.

Poltrock, S. E., \& Foltz, G. S. (1988). APT PC and APT II: Experiment development systems for the IBM PC and Apple II. 20, 201-205.

SCHNEIDER, W. (1988). Micro Experimental Laboratory: An integrated system for IBM PC compatibles. 20, 206-217.

SCHNEIDER, W. (1989). Enhancing a standard experimental deliv- ery system (MEL) for advanced psychological experimentation. 21, 240-244.

\section{Other}

Aldridge, J. W., \& Flores, S. A. (1988). Random figures and mirror images with variable complexity, size, and orientation in Applesoft BASIC. 20, 313-316.

BREMER, D. (1989). MINI-CPT: A continuous performance test program for the Tandy PC-8 Pocket Computer. 21, 11-14.

Burke, R. S. (1988). Production and control of auditory signals in attention research using the Apple-Psych system. 20, 171-174.

Gettys, C. F., \& Berglan, L. (1989). Laboratory MicroStar: A data-logging word processor for research on word processors. 21, 484-486.

Huff, C. W., \& RosenberG, J. (1989). The on-line voyeur: Promises and pitfalls of observing electronic interaction. 21, 166-172.

Kendall, R. A. (1988). A sample-to-disk system for psychomusical research. 20, 129-136.

Marshall-Goodell, B., Frei, L., \& Gormezano, I. (1989). A personal computer programmable sine-wave generator. 21, $431-434$

MundT. J. C. (1989). Computer-based preference models for generic multidimensional problem sets. 21, 121-124.

Palmer, C. (1989). Computer graphics in music performance research. 21, 265-270.

WILsON, M. (1988). MRC Psycholinguistic Database: Machineusable dictionary, version 2.00. 20, 6-10.

Yaphe, M., Raftery, E., \& Jamieson, D. G. (1989). A generalpurpose facility for adaptive testing in psychoacoustics. 21, 275-280.

\section{Perception and Sensation}

Anstis, S., \& Paradiso, M. (1989). Programs for visual psychophysics on the Amiga: A tutorial. 21, 548-563.

Boles, D. B., \& Clifford, J. E. (1989). An upper- and lowercase alphabetic similarity matrix, with derived generation similarity values. 21, 579-586.

Cohen, A. J., \& Mieszkowski, M. (1989). Frequency synthesis by the Commodore Amiga for research on perception and memory of pitch. 21, 623-626.

MARKS, W., \& GREER, J. B. (1989). A set of color-graphics routines for studying perceptual learning on the IBM-PC. 21, 574-578.

\section{Psycholinguistics}

Algarabel, S., Ruiz, J. C., \& Sanmartin, J. (1988). The University of Valencia's computerized word pool. 20, 398-403.

Beeman, M., \& Gernsbacher, M. A. (1988). Real-time language comprehension research using the Apple-Psych system. 20, 164-170.

WILSON, M. (1988). MRC Psycholinguistic Database: Machineusable dictionary, version 2.0. 20, 6-10.

\section{Reaction Time}

EMERSON, P. L. (1988). Using serial interfaces and the C language for real-time experiments. 20, 330-336.

Heathcote, A. (1988). Screen control and timing routines for the IBM microcomputer family using a high-level language. 20, 289-297.

Stoddard, P. K., \& Loftus, G. R. (1988). An IBM XT- 
compatible, computer-based, slide-projector laboratory. 20 , 541-551.

WRIGHT, R. D., \& DAWSON, M. R. W. (1988). Using hardware internupts for timing visual displays and reaction-time key interfacing on the Commodore 64 . 20, 41-48.

\section{Reading Research}

Lock, S., \& LeONG, C. K. (1989). Program library for DECtalk text-to-speech system. 21, 394-400.

Nason, S., \& ZabruCKY, K. (1988). A program for comprehension monitoring of text using HyperCard for the Macintosh. 20, 499-502.

WALCZYK, J. J., \& RoYeR, J. M. (1989). A program for constructing SVT tests: An alternative way of assessing text comprehension. 21, 369-370.

\section{Social}

STRUBE, M. J (1988). Three computer-automated social psychology laboratory tasks. $20,557-559$.

\section{Vision}

Anstis, S., \& Paradiso, M. (1989). Programs for visual psychophysics on the Amiga: A tutorial. 21, 548-563.

Ostrander, L. E., Kandel, G. L., Jenkins, P. L., \& Simon, J. W. (1989). A preferential looking clinical acuity test: Improvements in implemented microcomputer control. 21, $421-425$.

Stanislaw, H. (1989). Lookup tables for linear trajectories through color space. 21, 502-524.

Stork, D. G., \& RoccA, C. (1989). Software for generating autorandom-dot stereograms. 21, 525-534.

\section{SIMULATIONS AND MODELS}

\section{Conditioning}

LAChNIT, H., SChNedier, R. L., LiPP, O. V., \& KIMMEL, H. D. (1988). RWMODEL: A program in Turbo Pascal for simulating predictions based on the Rescorla-Wagner model of classical conditioning. 20, 413-415.

\section{Connectionist Models}

Greenbaum, J., \& Revlin, R. (1989). PSN: A Prolog declarative model of conceptual knowledge. 21, 15-23.

McClelland, J. L., \& Rumelhart, D. E. (1988). A simulationbased tutorial system for exploring parallel distributed processing. 20, 263-275.

Munro, P. W., \& Anderson, J. A. (1988). Tools for the connectionist modeling: The dynamical systems methodology. 20 , 276-281.

SCHNEIDER, W. (1988). Sensitivity analysis in connectionist modeling. 20, 282-288.

\section{Other}

Jones, J. A., Miller, B. O., \& SCarborough, D. L. (1988). A rule-based expert system for music perception. 20, 255-263.

\section{Psycholinguistics}

LIEBHABER, M. J. (1988). A computer model of inflection learning. 20, 246-254.
Vision

Landy, M. S., Manovich, L. Z., \& Stetten, G. D. (1989). All about EVE: The early vision emulation software. 21, 491-501.

\section{SOFTWARE}

\section{Evaluation and Comparison}

Anderson, M., Hornby, P., \& Bozak, D. (1988). COMPsych: A computerized software information system. 20, 243-245.

Butler, D. L. (1988). A critical evaluation of software for experiment development in research and teaching. 20, 218-220.

Butler, D. L., \& Neudecker, W. (1989). A comparison of inexpensive statistical packages for microcomputers running MSDOS. 21, 113-120.

\section{SPSS}

KIngma, J., \& TAERUM, T. (1988). A FORTRAN 77 program for a nonparametric item response model: The Mokken scale analysis. 20, $471-480$.

\section{SOUND}

Burke, R. S. (1988). Production and control of auditory signals in attention research using the Apple-Psych system. 20, 171-174.

Cohen, A. J., \& Mieszkowski, M. (1989). Frequency synthesis by the Commodore Amiga for research on perception and memory of pitch. 21, 623-626.

YAPHE, M., Raftery, E., \& Jamieson, D. G. (1989). A generalpurpose facility for adaptive testing in psychoacoustics. 21, 275-280.

\section{SPEECH}

Mertus, J. (1989). Standards for PCM files. 21, 126-129.

YAPHE, M., RAFTERY, E., \& JAMIESON, D. G. (1989). A generalpurpose facility for adaptive testing in psychoacoustics. 21, 275-280.

\section{Synthesized Speech}

LocK, S., \& LeONG, C. K. (1989). Program library for DECtalk text-to-speech system. 21, 394-400.

Wise, B., Olson, R., Anstett, M., \& Andrews, L., TerJAK, M., SChneider, V., KostuCh, J., \& KRIHo, L. (1989). Implementing a long-term computerized remedial reading program with synthetic speech feedback: Hardware, software, and real-world issues. $21,173-180$.

\section{Voice Recognition}

Boles, D. B. (1988). Voice recognition with the Apple-Psych system. 20, 158-163.

\section{STATISTICAL ANALYSIS}

\section{ANCOVA and follow-up tests}

DAwson, D. L. (1988). A BASIC factorial analysis of covariance program for three microcomputer families. $20,419$.

\section{ANOVA and follow-up tests}

Martin, S. A., \& ToOthaker, L. E. (1989). PERITZ: A 
FORTRAN program for performing multiple comparisons of means using the Peritz Q method. 21, 465-472.

Rossi, J. S. (1988). ONEWAY: A BASIC program for computing ANOVA from group summary statistics. 20, 347-348.

Vercruyssen, M., \& EdWARDS, J. C. (1988). ANOVA/TT: Analysis of variance teaching template for Lotus 1-2-3. 20, 349-354.

\section{Chi-Square}

DUNLAP, W. P. (1989). A program for exact power of the $2 \times 2$ chi-square. 21, 645-646.

\section{Correlations}

Brophy, A. (1988). A BASIC program for the multistage Bonferroni procedure for many correlations. 20, 416-418.

Dunlap, W. P., \& Kemery, E. R. (1988). Biserial and pointbiserial correlation with correction for nonoptimal dichotomies. 20, 420-422.

Silver, N. C., \& Hollingsworth, S. C. (1989). A FORTRAN 77 program for averaging correlation coefficients. $21,647-650$.

\section{Distributions}

Brophy, A. L., \& Wood, D. L. (1989). Algorithms for fast and precise computation of the normal integral. 21, 447-454.

Dawson, M. R. W. (1988). Fitting the ex-Gaussian equation to reaction time distributions. 20, 54-57

Emerson, P. L. (1988). FISHTAIL: Practical $F$ integration on small computers in BASIC and C. 20, 65-69.

WoOD, D. L. (1988). Advanced algorithms for the numerical integration of $t$. 20, 60-62.

\section{Factor Analysis}

longman, R. S., Cota, A. A., Holden, R. R., \& Fekken, G. C. (1989). PAM: A double-precision FORTRAN routine for the parallel analysis method in principal components analysis. 21, 477-480.

VOKEY, J. R. (1989). Matching factor structure using orthogonal rotation to congruence. $21,84-85$.

\section{Fourier Analysis}

Emerson, P. L. (1988). Compact C language Fourier analysis on small computers. 20, 423-426.

EMERSON, P. L. (1989). NEWSART: Negative binomial weighted spectral analysis in real time. 21, 353-368.

Yost, M., Bremner, F. J., \& Nasman, V. T. (1988). Using three-dimensional graphics in neuropsychological hypothesis testing. 20, 108-112.

\section{Game Theory}

Sakurai, M. M., \& Brennan, J. M. (1989). Computing the Harsanyi function $H(S)$ for $n$-person cooperative transferable utility normal form games. 21, 535-539.

Sakurai, M. M., \& Brennan, J. M. (1988). Computing the von Newmann-Morgenstern characteristic function $v(S)$ for cooperative $n$-person transferable utility normal form games. 20 , $367-371$.

\section{Lag Sequential Statistics}

Symons, D. K., Wright, R. D., \& Moran, G. (1988). Computing lag sequential statistics on dyadic time interval data: The TLAG program. 20, 343-346.

\section{Meta-analysis}

SChWARZER, R. (1988). Meta-analysis programs. 20, 338.

\section{Nonparametric Statistics}

Kingma, J., \& TAERUM, T. (1988). A FORTRAN 77 program for a nonparametric item response model: The Mokken scale analysis. 20, 471-480.

\section{Other}

Beins, B. C. (1989). An Applesoft BASIC program for the G-statistic: An alternative to the chi-square test. 21, 627-629.

BERRY, K. J. (1989). An APL function for the asymptotic test of significance for Goodman and Kruskal's gamma statistic. 21, 473-476.

BerRy, K. J., \& Mielke, P. W., JR. (1988). APL approximations for common statistical critical values. 20, 339-342.

Bremner, F. J., Yost, M., \& Nasman, V. T. (1989). Statistical analysis of fuzzy-set data from neuronal networks. 21, 209-212.

Brennan, J. M., Nitz, L. H., \& Daly, J. E. (1988). An APL program for measures of association for ordinal variables. 20 , 429-431.

Caciopro, J. T., Marshall-Goodell, B. S., Tassinary, L. G., Chen, F., Siegel, S. J., \& Dorfman, D. D. (1988). Waveform moment analysis: An ASYST program for topographical analyses of nonnegative bounded waveforms. 20, 517-527.

MalColm, D. S. (1989). A BASIC program for exploratory data analysis. 21, 463-464.

May, R. B., Masson, E. J., \& Hunter, M. A. (1989). Randomization tests: Viable alternatives to normal curve tests. 21, 482-483

Michener, H. A., Abrams, C. L., \& Ebert, R. F. (1989). MAUA145: A PASCAL program for multi-attribute utility analysis. 21, 651-652.

SchlottmanN, R. S. (1989). A BASIC program for classification analysis using proportional and maximum chance estimates of prior probabilities. 21, 636-638.

SCHNEIDER, W. (1988). Sensitivity analysis in connectionist modeling. 20, 282-288.

Wolach, A. H., \& McHale, M. A. (1988). Otthogonal comparisons. 20, 337.

Yost, M., Gindler, L., \& BRemner, F. J. (1988). Multivariate statistics and three-dimensional graphics. 20, 113-117.

\section{Regression}

ANSON, J. (1988). ROBREG: An APL procedure for fitting robust regression lines using Huber's M-estimate. 20, 579-582.

KRIEG, E. F., JR. (1988). A FORTRAN 77 program for the nuns test. 20, 361 .

Strube, M. J (1988). Calculation of significance regions for multiple predictors by the Johnson-Neyman technique. 20 , $510-512$.

\section{Scalings and Ratings}

KINGMA, J., \& TAERUM, T. (1988). A FORTRAN 77 program for a nonparametric item response model: The Mokken scale analysis. 20, 471-480.

Watkins, M. W., \& Kush, J. C. (1988). Micro-CONGRU: A microcomputer program for measuring levels of overall and partial congruence among multiple observers on nominal scales. 20, 513-514. 


\section{Statistical Packages}

BRADLEY, D. R. (1989). Computer simulation with DATASIM. 21, 99-112.

Butler, D. L., \& Neudecker, W. (1989). A comparison of inexpensive statistical packages for microcomputers running MS-DOS. 21, 113-120.

GallA, J. P. (1989). BASIC statistics for IBM computers: An integrated instructional statistical package. 21,481 .

Hodge, M. H., \& Pittenger, D. J. (1988). More statistical programs for Commodore computers. 20, 427-428.

WOLACH, A. H. (1988). ANOVA, Latin square, and ANCOVA for IBM-compatible microcomputer systems. 20, 585-586.

\section{Structural Equation Modeling}

BENJAFIELD, J. (1988). Solving path diagrams with EUREKA. 20, 307-309.

\section{STIMULUS GENERATION AND SELECTION}

Greene, S., Ratcliff, R., \& MCKoon, G. (1988). A flexible programming language for generating stimulus lists for cognitive psychology experiments. 20, 119-128.

TURNER, S. L., \& MACLEOD, C. M. (1988). SLIDE MAKER: A BASIC program to create $35-\mathrm{mm}$ slides of verbal materials. 20, 355-358.

\section{SYSTEMS}

\section{Mainframe}

\section{VAX}

Landy, M. S., Manovich, L. Z., \& Stetten, G. D. (1989). All about EVE: The early vision emulation software. 21, 491-501.

Martin, S. A., \& Toothaker, L. E. (1989). PERITZ: A FORTRAN program for performing multiple comparisons of means using the Peritz $Q$ method. 21, 465-472.

Silver, N. C. \& Hollingsworth, S. C. (1989). A FORTRAN 77 program for averaging correlation coefficients. 21, $647-650$.

\section{Microcomputer \\ Apple}

Aldridge, J. W., \& Flores, S. A. (1988). Random figures and mirror images with variable complexity, size, and orientation in Applesoft BASIC. 20, 313-316.

Barnes, S., \& Burke, R. S. (1988). What is Apple-Psych? 20, 150-154.

BARO, J. A., \& LehmKuhle, S. (1988). A software system for recording and analyzing transient evoked potential data with an Apple Ile computer. 20, 515-51.

Beeman, M., \& Gernsbacher, M. A. (1988). Real-time language comprehension research using the Apple-Psych system. 20, 164-170.

Beins, B. C. (1989). An Applesoft BASIC program for the $G$-statistic: An alternative to the chi-square test. 21, 627-629.

Biggs, T. C., Pulham, D., \& Bleasdale, F. A. (1988). Apple slide tachistoscope. 20, 49-53.

BoLEs, D. B. (1988). Voice recognition with the Apple-Psych system. 20, 158-163.

Boles, D. B., \& ClifFord, J. E. (1989). An upper- and lowercase alphabetic similarity matrix, with derived generation similarity values. $21,579-586$.
Burke, R. S. (1988). Production and control of auditory signals in attention research using the Apple-Psych system. 20, 171-174.

ButLer, D. L. (1988). A critical evaluation of software for experiment development in research and teaching. 20, 218-220.

DAwson, D. L. (1988). A BASIC factorial analysis of covariance program for three microcomputer families. 20, 419.

EAmON, D. B. (1988). Enhancing Applesoft using ampersand routines. 20, 224-230.

EAMON, D. B. (1989). Screen display and timing synchronization on the Apple Ile and Apple IIgs. 21, 426-430.

Ergener, D., \& Wellens, A. R. (1989). DataVision: A computer-based system for generating and reading digital information accompanying video images on videotape. 21, $401-407$.

Jouen, F., \& LEPECQ, J.C. (1989). Optical and electronic systems for spatial and temporal analysis of video images. 21 , 2-10.

Krauss, R. M., Morrel-Samuels, P., \& HochberG, J. (1988). VIDEOLOGGER: A computerized multichannel event recorder for analyzing videotapes. 20, 37-40.

Marshall-Goodell, B., Frei, L., \&ormezano, I. (1989). A personal computer programmable sine-wave generator. 21, $431-434$

Merbitz, C., Grip, J., \& Marqui, H. P. (1988). A jiffy clock for the Apple IIc, II +, and Ile with a mouse. 20, 362.

Mitterer, J., \& ADAMs-Webeer, J. (1988). OMNIGRID: A general repertory grid design, administration, and analysis program. 20, 359-360.

OsGood, G. (1988). Generalizing the Apple-Psych system. 20, 155-157.

Peterson, S. B. (1989). A microcomputer lab for psychology based on a hierarchical learning model. 21, 130-133.

Poltrock, S. E., \& Foltz, G. S. (1988). APT PC and APT II: Experiment development systems for the IBM PC and Apple II. 20, 201-205.

Turner, S. L., \& MACLEod, C. M. (1988). SLIDE MAKER: A BASIC program to create $35-\mathrm{mm}$ slides of verbal materials. 20, 355-358.

VOKEY, J. R. (1989). Matching factor structures using orthogonal rotation to congruence. $21,84-85$.

WatKInS, M. W., KUSH, J. C. (1988). Micro-CONGRU: A microcomputer program for measuring levels of overall and partial congruence among multiple observers on nominal scales. 20, 513-514.

\section{Commodore 128}

Strube, M. J (1988). A BASIC program for the generation of Latin squares. 20, 508-509.

Strube, M. J (1988). Calculation of significance regions for multiple predictors by the Johnson-Neyman technique. 20 , 510-512.

\section{Commodore 64}

Dawson, M. R. W. (1988). Fitting the ex-Gaussian equation to reaction time distributions. 20, 54-57.

Hodge, M. H., \& Pittenger, D. J. (1988). More statistical programs for Commodore computers. 20, 427-428.

PIEPER, W., \& LACHNIT, H. (1989). C64-to-PC: Transmitting data from a Commodore C64 to IBM-compatible PC's. 21, 653.

STRUBE, M. J (1988). Three computer-automated social psy chology laboratory tasks. 20, 557-559. 
WrIGHT, R. D., \& Dawson, M. R. W. (1988). Using hardware interrupts for timing visual displays and reaction-time key interfacing on the Commodore 64. 20, 41-48.

\section{Commodore Amiga}

Anstis, S., \& Paradiso, M. (1989). Programs for visual psychophysics on the Amiga: A tutorial. 21, 548-563.

COHEN, A. J., \& MieszKowski, M. (1989). Frequency synthesis by the Commodore Amiga for research on perception and memory of pitch. 21, 623-626.

CONLEY, J. (1989). An experiment control system for the Amiga microcomputer. 21, 391-393.

Tanner, P. P., Jolicoeur, P., Cowan, W. B., Booth, K., \& Fishman, F. (1989). Antialiasing: A technique for smoothing jagged lines on a computer graphics image -an implementation on the Amiga. 21, 59-66.

\section{IBM}

Adedi, J., \& Shavelson, R. (1988). FRACTION: A computer program for fractional factorial design. 20, 58-59.

ANSON, J. (1988). ROBREG: An APL procedure for fitting robust regression lines using Huber's M-estimate. 20, $579-582$

BENJAFIELD, J. (1988). Solving path diagrams with EUREKA. 20, 307-309.

BENTE, G. (1989). Facilities for the graphical computer simulation of head and body movements. 21, 455-462.

Berry, K. J., \& MiflKe, P. W., JR. (1988). APL approximations for common statistical critical values. 20, 339-342.

BRADLEY, D. R. (1989). Computer simulation with DATASIM. 21, 99-112.

Brennan, J. M., Nitz, L. H., \& Daly, J. E. (1988). An APL program for measures of association for ordinal variables. $\mathbf{2 0}$, 429-431.

BROPHY, A. (1988). A BASIC program for the multistage Bonferroni procedure for many correlations. 20, 416-418.

Brysbaert, M., Bovens, N., D'Ydewalle, G., \& Van CalSTER, J. (1989). Turbo Pascal timing routines for the IBM microcomputer family, 21, 73-83.

BUTLER, D. L. (1988). A critical evaluation of software for experiment development in research and teaching. 20, 218-220.

Butler, D. L., \& Neudecker, W. (1989). A comparison of inexpensive statistical packages for microcomputers running MS-DOS. 21, 113-120.

Cacioppo, J. T., Marshall-Goodell, B. S., Tassinary, L. G., Chen, F., Siegel, S. J., \& Dorfman, D. D. (1988). Waveform moment analysis: An ASYST program for topographical analyses of nonnegative bounded waveforms. 20 , 517-527.

Carver, C. S., Dunham, R. G., Spitzer, M. W., \& Delgado, L. M. (1988). A tracking program to schedule subjects across multipanel longitudinal research. 20, 576-578.

Crosbie, J. (1989). A simple Turbo Pascal 4.0 program for millisecond timing on the IBM PC/XT/AT. 21, 408-413.

D'ANDREA, J. A., \& KNEPTON, J. (1988). Construction and implementation of a low-cost electronic experiment control interface. 20, 97-99.

DAwson, D. L. (1988). A BASIC factorial analysis of covariance program for three microcomputer families. $20,419$.

DLHOPOLSKY, J. G. (1988). C language functions for millisecond timing on the IBM PC. 20, 560-565.

Dlhopolsky, J. G. (1989). Synchronizing stimulus displays with millisecond timer software for the IBM PC. 21, 441-446.
DUNlaP, W. P., \& Kemery, E. R. (1988). Biserial and pointbiserial correlation with correction for nonoptimal dichotomies. 20, 420-422.

Eiler, J. M., Nelson, W. W., Jensen, C. C., \& Johnson, S. P. (1989). Automated data collection using bar code. 21, 53-58.

Emerson, P. L. (1988). Compact C language Fourier analysis on small computers. 20, 423-426.

EMERSON, P. L. (1988). FISHTAIL: Practical $F$ integration on small computers in BASIC and C. 20, 65-69.

EMERSON, P. L. (1988). The best crude timer for MS-DOS implementations of C. 20, 583-584.

EMERSON, P. L. (1988). TIMEX: A simple IBM AT C language timer with extended resolution. 20, 566-572.

EMERSON, P. L. (1988). Using serial interfaces and the C language for real-time experiments. 20, 330-336.

FINLEY, G. P. (1989). Tachistoscopic software for the Hercules display controller. 21, 387-390.

Franks, I. M. (1988). A method for investigating the sequential ordering of simple movement patterns: An IBM-based application using the Tecmar Labmaster. 20, 298-306.

Galla, J. P. (1989). BASIC statistics for IBM computers: An integrated instructional statistical package. 21, 481

GARCíA-PÉREZ, M. A. (1988). HDC: A subroutine library for image processing using Burt's hierarchical discrete correlation. 20, 317-329.

Gettys, C. F., \& Berglan, L. (1989). Laboratory MicroStar: A data-logging word processor for research on word processors. 21, 484-486.

GranaAs, M. M. (1989). TIMEX2: A modified C-language timer for PC-AT class machines. 21, 619-622.

Graves, R., \& Bradley, R. (1988). More on millisceond timing and tachistoscope applications for the IBM PC. 20, 408-412.

Heathcote, A. (1988). Screen control and timing routines for the IBM microcomputer family using a high-level language. 20, 289-297.

HoRnBy, P., \& ANDERSON, M. (1988). Using computers in introductory psychology. 20, 180-183.

Kahana, M. J., \& Detterman, D. K. (1989). ABC: A program to convert PSYCHLIT CD-ROM abstracts into APAstyle bibliographies. 21, 414 .

KaPlan, H. L., \& Noldy, N. E. (1989). A general framework for defining evoked potential paradigms. 21, 285-293.

KENDALL, R. A. (1988). A sample-to-disk system for psychomusical research. 20, 129-136.

KINGMA, J., \& TAERUM, T. (1988). A FORTRAN 77 program for a nonparametric item response model: The Mokken scale analysis. $20,471-480$.

KRIEG, E. F., JR. (1988). A FORTRAN 77 program for the runs test. 20, 361 .

LACHNIT, H., SCHNEDIER, R. L., LIPP, O. V., \& KiMmel, H. D. (1988). RWMODEL: A program in Turbo Pascal for simulating predictions based on the Rescorla-Wagner model of classical conditioning. 20, 413-415.

Landy, M. S., Manovich, L. Z., \& Stetten, G. D. (1989). All about EVE: The early vision emulation software. 21, 491-501.

Lavond, D. G., \& Steinmetz, J. E. (1989). An inexpensive interface for the IBM PC/XT and compatibles. 21, 435-440.

Leith, C. R., Hamm, H. D., Duncanson, C., \& Senical, T. (1988). A computer-driven undergraduate laboratory curriculum and related support logistics. 20, 188-190.

Lock, S., \& LeONG, C. K. (1989). Program library for DECtalk text-to-speech system. 21, 394-400. 
LORDAHL, D. S. (1988). Repairing the Microsoft BASIC RND function. 20, 221-223.

Malcolm, D. S. (1989). A BASIC program for exploratory data analysis. 21, 463-464.

Maloney, L. T., \& KoH, K. (1988). A method for calibrating the spatial coordinates of a visual display to high accuracy. 20, 372-389.

MARKS, W., \& GreER, J. B. (1989). A set of color-graphics routines for studying perceptual learning on the IBM-PC. 21, 574-578.

Marshall-Goodell, B., Frei, L., \& Gormezano, I. (1989). A personal computer programmable sine-wave generator. 21 , $431-434$

May, R. B., Masson, E. J., \& Hunter, M. A. (1989). Randomization tests: Viable alternatives to normal curve tests. 21, 482-483.

McConkie, G. W., Scouten, C. W., Bryant, P. K., \& WILSON, J. (1988). A microcomputer-based software package for eye monitoring research. 20, 142-149.

Michener, H. A., Abrams, C. L., \& Ebert, R. F. (1989). MAUA145: A PASCAL program for multi-attribute utility analysis. 21, 651-652.

Mundt, J. C. (1989). Computer-based preference models for generic multidimensional problem sets. 21, 121-124.

Ostrander, L. E., Kandel, G. L., Jenkins, P. L., \& Simon, J. W. (1989). A preferential looking clinical acuity test: Improvements in implemented microcomputer control. 21, 421-425.

Pevey, M. E. (1988). Using an IBM PC to network Walter/ Palya experiment controllers. 20, 100-103.

Pieper, W., \& LAChnit, H. (1989). C64-to-PC: Transmitting data from a Commodore C64 to IBM-compatible PC's. 21, 653.

Poltrock, S. E., \& FolTZ, G. S. (1988). APT PC and APT II: Experiment development systems for the IBM PC and Apple II. 20, 201-205.

Ransdell, S., \& Levy, C. M. (1989). A flexible and interactive software package for a laboratory in cognition and perception. 21, 160-162.

REDMOND, R. T., \& GASEN, J. B. (1988). PAST: Viewing the programming process. $20,503-507$.

Rose, D. (1988). ZSCORE: A program for the accurate calculation of $z$ scores, $d^{\prime}$, and $\beta$. 20, 63-64.

RossI, J. S. (1988). ONEWAY: A BASIC program for computing ANOVA from group summary statistics. 20, 347-348.

SchlotrmanN, R. S. (1989). A BASIC program for classification analysis using proportional and maximum chance estimates of prior probabilities. 21, 636-638.

SCHNEIDER, W. (1988). Micro Experimental Laboratory: An integrated system for IBM PC compatibles. 20, 206-217.

SCHNEIDER, W. (1989). Enhancing a standard experimental delivery system (MEL) for advanced psychological experimentation. 21, 240-244.

SCHWARZER, R. (1988). Meta-analysis programs. 20, 338.

Segalowitz, S. J. (1988). IBM PC tachistoscope: II. Assembly language subroutines. 20, 432.

Silverman, R. W., Chang, A. S., \& Russell, R. W. (1988). A microcomputer-controlled system for measuring reactivity in small animals. 20, 495-498.

Silverman, R. W., Chang, A. S., \& Russell, R. W. (1988). Measurement of activity in small animals using a microcomputer-controlled system. 20, 537-540.

Stoddard, P. K., \& Loftus, G. R. (1988). An IBM XTcompatible, computer-based, slide-projector laboratory. 20 , 541-551.
Stout, C. E. (1988). Personal computer software for teaching differential psychodiagnostics. 20, 106-107.

Symons, D. K., Wright, R. D., \& Moran, G. (1988). Computing lag sequential statistics on dyadic time interval data: The TLAG program. 20, 343-346.

TATHAM, T. A., \& ZURN, K. R. (1989). The MED-PC experimental apparatus programming system. 21, 294-302.

VERCRUYSSEN, M., \& EDWARDS, J. C. (1988). ANOVA/TT: Analysis of variance teaching template for Lotus 1-2-3. 20, 349-354.

VOKEY, J. R. (1989). Matching factor structures using orthogonal rotation to congruence. $21,84-85$.

WALCZYK, J. J., \& RoYER, J. M. (1989). A program for constructing SVT tests: An alternative way of assessing text comprehension. 21, 369-370.

WOLACH, A. H. (1988). ANOVA, Latin square, and ANCOVA for IBM-compatible microcomputer systems. 20, 585-586.

Wolach, A. H., \& McHale, M. A. (1988). Orthogonal comparisons. 20, 337.

Woon, D. L. (1988). Advanced algorithms for the numerical integration of $t .20,60-62$.

YAPHe, M., Raftery, E., \& Jamieson, D. G. (1989). A general-purpose facility for adaptive testing in psychoacoustics. 21, 275-280.

\section{Macintosh}

Algarabel, S., Sanmartin, J., \& Ahuir, F. (1989). A voiceactivated key for the Apple Macintosh computer. 21, 67-72.

Barnes, H. J., Vaughan, J., Jorgensen, M. J., \& RosenBAUM, D. A. (1989). A low-cost method for digitizing videotaped continuous movements on the Macintosh. 21, 255-258.

Brooks, J. O., III, \& Bieber, L. L. (1988). Digitized nonobjects for use with the Apple Macintosh computer. 20, 433-434.

ButLer, D. L. (1988). A critical evaluation of software for experiment development in research and teaching. 20, 218-220.

Conn, G., Stafiniak, P., DiPasquale, M. C., \& HarPer, L. (1988). Effects of teaching an introductory psychology laboratory using a computerized research tool. 20, 184-187.

Cooper, L. D., GariCa, R., \& GibBon, J. (1988). The labtop Macintosh: An interface and communications software for experiment control of animal learning research. 20, 88-92.

Costin, D. (1988). MacLab: A Macintosh system for psychology labs. 20, 197-200.

Eiler, J. M., Nelson, W. W., Jensen, C. C., \& Johnson, S. P. (1989). Automated data collection using bar code. 21, 53-58.

Geisler-Brenstein, E., \& Brenstein, R. J. (1989). The potential of HyperCard for psychological research and instruction: A general discussion and description of two research applications. 21, 307-311.

Hatten, J. L., \& Hatten, A. D. (1989). Implementing an undergraduate research apprenticeship with the Macintosh computer. 21, 142-147.

HewetT, T. T. (1989). The Drexel Disk: Hypertext-based instructional software as a tool for the exploration of a constrained knowledge system. 21, 316-325.

JoRgensen, P., RuCKer, T. J., \& REYNolds, J. H. (1989). A Pascal function for presenting MacPaint files on the Macintosh. 21, 415-419.

Kieley, J. M., \& Higgins, T. S. (1989). Precision timing options for the Apple Macintosh family of computers. 21, 259-264.

LATIMER, C. R. (1988). Eye-movement data: Cumulative fixation time and cluster analysis. 20, 437-470. 
Martin, T. A., \& Wilcox, K. L. (1989). HyperCard administration of a block-design task. 21, 312-315.

NaSON, S., \& ZABRUCKY, K. (1988). A program for comprehension monitoring of text using HyperCard for the Macintosh. 20, 499-502.

Stork, D. G., \& RoccA, C. (1989). Software for generating auto-random-dot stereograms. 21, 525-534.

VoKEY, J. R. (1989). Matching factor structures using orthogonal rotation to congruence. 21, 84-85.

Weisman, R., \& Palya, W. (1988). Development and operating environments for a network of Walter/Palya experiment controllers on the Macintosh computer. 20, 93-96.

Westall, R. F., Perkey, M. N., \& Chute, D. L. (1989). Millisecond timing on the Apple Macintosh: Updating Drexel's MilliTimer. 21, 540-547.

\section{Radio Shack Color Computer}

DAwson, D. L. (1988). A BASIC factorial analysis of covariance program for three microcomputer families. $20,419$.

\section{TRS-80}

Emerson, P. L. (1988). FISHTAIL: Practical $F$ integration on small computers in BASIC and C. 20, 65-69.

Silverman, R. W., Chang, A. S., \& Russell, R. W. (1988). A microcomputer-controlled system for measuring reactivity in small animals. 20, 495-498.

Silverman, R. W., Chang, A. S., \& Russell, R. W. (1988). Measurement of activity in small animals using a microcomputer-controlled system. 20, 537-540.

\section{Minicomputer DEC PDP-11}

Edgell, S. E., \& Hertel, S. A. (1989). Running laboratory experiments using the RSX operating system and FORTRAN on the PDP-11. 21, 303-306.

\section{TESTING}

Geisler-Brenstein, E., \& Brenstein, R. J. (1989). The potential of HyperCard for psychological research and instruction: A general discussion and description of two research applications. 21, 307-311.

\section{Instructional Testing \\ Computer Administration}

Lee-Sammons, W. H., \& Wollen, K. A. (1989). Computerized practice tests and effects on in-class exams. 21, 189-194.

\section{Psychological Testing}

Martin, T. A., \& Wilcox, K. L. (1989). HyperCard administration of a block-design task. 21, 312-315.

MitTerer, J., \& ADAMS-WebBer, J. (1988). OMNIGRID: A general repertory grid design, administration, and analysis program. 20, 359-360.

\section{THEORY OF SIGNAL DETECTABILITY}

ROSE, D. (1988). ZSCORE: A program for the accurate calculation of $z$ scores, $d^{\prime}$, and $\beta$. 20, 63-64.

\section{VIDEO TECHNOLOGY}

Barnes, H. J., Vaughan, J., Jorgensen, M. J., \& RosenBAUM, D. A. (1989). A low-cost method for digitizing videotaped continuous movements on the Macintosh. 21, 255-258.

Barnes, O., Haith, M. M., \& RoberTs, R. J. (1988). Simultaneous electronic recording of video and digital information on the video channel of a VTR or VCR. 20, 32-36.

Ergener, D., \& Wellens, A. R. (1989). DataVision: A computer-based system for generating and reading digital information accompanying video images on videotape. 21, 401-407.

JoUEN, F., \& LePECQ, J.C. (1989). Optical and electronic systems for spatial and temporal analysis of video images. 21, 2-10.

Krauss, R. M., Morrel-Samuels, P., \& Hochberg, J. (1988). VIDEOLOGGER: A computerized multichannel event recorder for analyzing videotapes. 20, 37-40.

Ourvo, R. F., \& THOMPSON, M. C. (1988). Monitoring animals' movements using digitized video images. 20, 485-490.

Pear, J. J., Silva, F. J., \& Kincaid, K. M. (1989). Threedimensional spatiotemporal imaging of movement patterns: Another step toward analyzing the continuity of behavior. 21, 568-573.

STAPPERS, P. J. (1988). Improved calibration of color video projectors by means of computer animation. 20, 573-575.

\section{VISUAL DISPLAY SYSTEM}

Eamon, D. B. (1989). Screen display and timing synchronization on the Apple IIe and Apple IIgs. 21, 426-430.

HeATHCOTE, A. (1988). Screen control and timing routines for the IBM microcomputer family using a high-level language. 20, 289-297.

Jorgensen, P., Rucker, T. J., \& Reynolds, J. H. (1989). A Pascal function for presenting MacPaint files on the Macintosh. 21, 415-419.

MalONEY, L. T., \& KoH, K. (1988). A method for calibrating the spatial coordinates of a visual display to high accuracy. 20, 372-389.

MARKS, W., \& GREER, J. B. (1989). A set of color-graphics routines for studying perceptual learning on the IBM-PC. 21, 574-578.

\section{Tachistoscope}

Biggs, T. C., Pulham, D., \& Bleasdale, F. A. (1988). Apple slide tachistoscope. 20, 49-53.

DLHOPOLSKY, J. G. (1989). Synchronizing stimulus displays with millisecond timer software for the IBM PC. 21, 441-446.

FINLEY, G. P. (1989). Tachistoscopic software for the Hercules display controller. 21, 387-390.

Graves, R., \& Bradley, R. (1988). More on millisceond timing and tachistoscope applications for the IBM PC. 20, 408-412.

Segalowitz, S. J. (1988). IBM PC tachistoscope: II. Assembly language subroutines. $20,432$.

Stoddard, P. K., \& LofTus, G. R. (1988). An IBM XTcompatible, computer-based, slide-projector laboratory. 20 , 541-551.

Wright, R. D., \& DAwson, M. R. W. (1988). Using hardware interrupts for timing visual displays and reaction-time key interfacing on the Commodore 64. 20, 41-48. 